\section{REGISTRO PÚBLICO DE PROJETOS DE PESQUISA}

0 pesquisador quando recebe uma sugestão ou possui uma idéia ou uma dúvida, surgida no exercício profissional, necessita desenvolvê-la em nível experimental ou clínico.

$\mathrm{N}$ o início da história normativa, nada Ihe competia a não ser executar a investigação e comunicar o seu resultado. Liberdade absoluta. 0 rganizaram-se os serviços passando- Ihes o controle. 0 chefe ou o catedrático tomava conhecimento, aceitava a proposta, autorizava e, participando ou não, desenvolvia-se a pesquisa que aparecia como produção do serviço.

A universidade mudou seus rumos administrativos e políticos. C resceu, agigantou-se e, conseqüentemente, complicouse. Segmentos novos surgiram, mais autoridades e mais pessoas para opinarem num encaminhamento.

Para realizar uma pesquisa, hoje, tem-se que seguir, mais ou menos, os seguintes caminhos: sugestão ou idéia; fazer 0 projeto minucioso; submetê-lo ao orientador ou ao chefe do setor; aprovação; solicitação ao chefe do departamento afim; encaminhamento, por este, a um relator; submissão do seu parecer à câmara departamental; discussão em plenário; aprovação; solicitação ao biotério para disponibilidade de animal, se a pesquisa for experimental; solicitação ao coordenador de pesquisa e ensino do hospital para que autorize, caso se trate de pesquisa "in anima nobili", também discutido numa câmara menor em número de membros; se é experimental, o projeto segue para discussão na câmara da Comissão Reguladora de Pesquisa em Animal; se é clínico ou envolvendo seres humanos, o projeto será dado a um relator na Comissão de Pesquisa em Seres H umanos (Coep); discussão do parecer e aprovação; se há necessidade de ajuda financeira do hospital, a diretoria administrativa tem que ser ouvida; se há ajuda da faculdade de medicina, o diretor tem que tomar conhecimento e encaminhálo para parecer e discussão na congregação; se a ajuda for de órgãos de fomento (Capes, Fapemig, CN Pq...), o projeto será enviado para parecer e liberação; se houver envolvimento ético de qualquer natureza, a Comissão de Ética (Coet) do hospital será ouvida para autorização...

Se 0 assunto envolve seres humanos e a pesquisa será realizada em genética, índios, sidosos (Aids)... o projeto tem que ser enviado para relatório, discussão e aprovação na Comissão $\mathrm{N}$ acional de Experimentação em Seres Humanos (Conep).

N essa altura o pesquisador já está exausto ou o iniciante já pensa em desistir.

Correndo tudo bem a investigação está autorizada. Só será realizada se o pesquisador mantiver boa relação com os funcionários ou tratar do pagamento pelo seu trabalho.

$\mathrm{N}$ ão se contando, nessa longa caminhada, os acertos de amizade, a troca de gentilezas, superação de resistências e, sobretudo, as dificuldades geradas pela inveja ou pelo aproveitamento da idéia e com a esperança de que ela não seja desenvolvida antes da fonte original. Felizmente, essa dificuldade é rara porque os pares se entendem e se respeitam ou até se prestigiam mutuamente.

Para um pesquisador experiente que acredita no que faz, ou que dependa para sobreviver e aumentar o seu ganho monetário, essas dificuldades são superadas ou já possui um esquema que lhe facilita montar o projeto e acompanhá-lo no seu seguimento com mais rapidez.

0 que me preocupa nesse peregrinar burocrático são três pontos. No primeiro, é o tempo despendido que poderia aplicar-se melhor no andamento e na reflexão sobre os resultados obtidos. No segundo, é perder-se parte ou toda a originalidade de uma idéia individual. Deve-se dividi-la, mas somente após as conclusões e a divulgação, em apresentações ou revistas especializadas.

0 terceiro ponto, que é destaque, é o comprometimento da criatividade. É natural que uma idéia deve ser repassada quando já a aprovamos ou a aplicamos. Diante de um roteiro demorado e complexo, envolvendo vários pares, é impossível que algo importante não vaze pelos corredores e possa ser experimentado antes que 0 original se realize. Não é duvidar da integridade humana, mas sabe-se do a proveitamento das boas coisas até sem más-intenções. 0 risco existe, não se pode negar.

Criar é trabalho, experimentação, persistência, resistência e, sobretudo, reflexão. Como refletir com segurança se se imagina que no decorrer burocrático sua proposta poderia ser aproveitada antes de realizá-la?

0 prejuízo é duplo, para o pesquisador e para a instituição.

Como resolver?

Criar, no máximo, três etapas: idéia, projeto e liberação pelo diretor (chefe) mais próximo ao local de realização da pesquisa (diretor do hospital, faculdade ou instituição; chefe do laboratório específico ou chefia do órgão de fomento).

Para que o corra essa simplificação, que não significa retorno à origem histórica do processo, é preciso que se considere 0 homem. $\mathrm{No}$ caso de pesquisa, o homem é 0 orientador ou 0 pesquisador qualificado na matéria e na ética.

Para o iniciante, há necessidade de quatro etapas, sendo a primeira liberada pelo pesquisador maduro ou seu orientador qualificado e as outras três como no exposto acima.

Esse fluxo simples só poderá ser executado se contar com o homem. Pesquisador experiente, conceituado, reconhecido pela comunidade e respeitado pelos pares. Ele é a própria ética. Seu caráter humano e sua conduta de pesquisador, historicamente, o dispensam de fazer toda aquela peregrinação .

Tratando-se de iniciante, ou ainda não estabelecido conceitualmente, a aprovação por parte do orientador-sênior 0 dispensa da mesma peregrinação.

0 fato de estarmos sonhando com essa quimera reflete-se em dois aspectos: o econômico e a certeza de que vale a pena introduzir-se no campo da pesquisa. 


\section{orrespondências}

No econômico, óbvio está que se ganha ou não se gasta tanto tempo com burocracia e nem se gasta tanto material, economia que seria aplicada à implementação da pesquisa.

$\mathrm{N} O$ aspecto valer a pena, evita-se que muitos jovens entusiasmados e sonhadores não desistam da esperança de se iniciarem e se tornarem seniores na investigação. 0 mais humilde, o mais recatado, o mais desprovido de proteções pessoais e o menos aquinhoado, certamente, perante tantas dificuldades que agora se colocam, desiste no início ou vê arrefecido o seu entusiasmo. A perda será grande em número e qualidade. Tantos bons serão perdid os desde o início e tantos insuficientes serão testados, logo no princípio, não ocupando espaço e tempo reservado aos melhores.

0 pior disso tudo é marginalizar o homem, a idéia e a criatividade. Não se cria com burocracia. Esta obnubila a esperança, o sonho, a idéia fértil e a capacidade de trabalho inerente aos bons.

Alcino lázaro da Silva Belo Horizonte - MG

Referências

Caramelli B. 0 registro público obrigatório de ensaios clínicos. Rev Assoc M ed Bras. 2005;51(16):301 